\title{
Cooling System for Primary Low Temperature Processing and Storage of Grains of Small Frachioned
}

\author{
S. Petushenko \\ Odessa Technical College of Odessa National Academy of Food Technologies, \\ 54 Balkivska st., Odessa, 65006, Ukraine \\ E-mail: sergeinp1965@gmail.com
}

The analysis of different aspects of grain refrigeration on elevators of Ukraine, Commonwealth of Independent States and in the world is carried out. The advantage of the refrigeration method is shown concerning the quality and of energy conservation. A comparative analysis of various types of refrigeration machines operating on ozone-friendly refrigerants has been carried out. It is shown that it is more profitable to use heat that is worked out from refrigerating machines.

Key words: Refrigeration Systems, Systems of Primary Refrigeration, Storage of Small Fractioned Cultures, Heat Exchange of a Fixed Layer.

(C) The Author(s) 2017. This article is an open access publication

This work is licensed under the Creative Commons Attribution 4.0 International License (CC BY) http://creativecommons.org/licenses/by/4.0/



\section{Introduction}

The solution of the problems of the country's food security in the parameters set by the Law of Ukraine "On Food Security of Ukraine" and the stabilization of food prices are primarily related to the development of its own high-tech and competitive agro-industrial production.

The most important problems of the agro-industrial complex were and still are insufficient depth of processing of agricultural raw materials and high losses during the storage. To solve these problems, it is necessary to develop the food and processing industry, the material and technical base storage, and also, the creation of modern storage facilities for primary products of conditions for the modernization of food and processing industry enterprises through technical re-equipment based on innovative resource-saving technologies [1].

Agriculture is a branch of the economy aimed at providing the population with food and obtaining raw materials for a number of industrial areas. It is one of the most important sectors for the population, as well as the functioning of the state. Cereal crops are the predominant branch of agriculture.

Grain is one of the most important human basic foodstuffs, for cultivation and collection of which extensive resources are attracted. Post-harvest processing and storage is a key link in the production of grain. According to the UN Food and Agriculture Organization, in the world about $20 \%$ of the collected grain is spoiled annually [2]. The main task of grain storage is to save grain without losses in mass or with minimal losses. Losses caused by a decrease in the quality of stored grain lead to quantitative losses.

The increase in grain dry capacity in recent years has been mainly in the way of increasing the capacity of individual devices to ensure harvesting in a short time. The introduction of the commodity classification of grain products also determined the need to improve the technology of post-harvest processing of grain products, including for various in terms of volume and quality of grain lots.

Existing high-temperature grain dryers do not yet have a flexible technological scheme that allows drying under optimal conditions, depending on the initial humidity and grain quality, require additional solutions for cooling grain after drying and for temporary storage, including using artificially refrigerated coolants.

In the process of drying, a significant amount of scarce light oil products is consumed, and existing combustion devices, especially those equipped with heat exchangers, have a low coefficient of efficiency.

Existing active ventilation systems have low specific air supply, significant metal consumption and insufficient reliability, in most cases the drying and active ventilation process are considered separately and do not complement each other. The lack of necessary research does not allow the use of grain refrigeration technology, high-temperature drying and active ventilation for the processing of grain products, which is especially important for preserving the quality of grain, especially small seeds.

As shown by many years of experience in the technology of primary processing of freshly harvested grain, one of the most urgent tasks is its cooling to temperatures that ensure safe storage. Numerous physiological, biochemical and technological studies have established that a decrease in the grain temperature below $8 \ldots 10^{\circ} \mathrm{C}$ sharply reduces the intensity of physiological and biochemical processes, contributes to maintaining the initial quality of the grain, and increases the shelf life of the grain both during long-term grain storage and during its temporary storage to possible additional treatment in the dryer [3]. Thus, the problem of developing primary refrigeration systems for small seeds is actual. 


\section{Analysis of existing refrigeration systems for prima- ry processing and storage of grain. Formulation of the problem}

When choosing the method of primary grain processing with cold at a temperature of $8 \ldots 10^{\circ} \mathrm{C}$, technologists take in view of quality factors, minimizing losses, saving financial costs, labor and energy resources, environmental issues [3-9]. Improving the quality of stored grain at low temperatures is associated with the elimination of favorable conditions for the development of mold fungi [3-6] and, respectively, the exclusion of chemical grain processing [6]. Minimization of grain losses during low-temperature storage is determined by the decrease in the vital activity of insects at temperatures below $13{ }^{\circ} \mathrm{C}$ - insects fall into hibernation and do not harm the stored grain [4-6].

Saving financial costs, labor and energy resources for lowtemperature storage of grain is due to the fact that:

a) cooling complexes can be placed directly at harvest sites and excluded

grain losses during re-stocking (reach $0.03 \%$ of the total $[7,8]$ and save on technological transport facilities [8];

b) grain and seeds of oil crops with high humidity are stored at a temperature of $8 \ldots 10{ }^{\circ} \mathrm{C}$ without deterioration of quality over a long period of time (Table 1), and this makes it possible to alleviate the problem drying during the harvest period [3].

Table 1 - Duration of grain storage, depending on the initial humidity and storage temperature [9]

\begin{tabular}{|c|c|c|c|c|c|c|}
\hline \multirow{2}{*}{$\begin{array}{c}\text { Initial } \\
\text { humi- } \\
\text { dity, } \\
\%\end{array}$} & \multicolumn{2}{|c|}{ Seed grain } & \multicolumn{2}{|c|}{ Food grain } & \multicolumn{2}{|c|}{ Fodder grain } \\
\hline & \begin{tabular}{|c} 
The stor- \\
age tem- \\
perature, \\
${ }^{\circ} \mathrm{C}$
\end{tabular} & $\begin{array}{l}\text { Dura- } \\
\text { tion of } \\
\text { storage }\end{array}$ & $\begin{array}{l}\text { The stor- } \\
\text { age tem- } \\
\text { perature, } \\
{ }^{\circ} \mathrm{C}\end{array}$ & $\begin{array}{c}\text { Duration } \\
\text { of stor- } \\
\text { age }\end{array}$ & $\begin{array}{l}\text { The stor- } \\
\text { age tem- } \\
\text { perature, } \\
{ }^{\circ} \mathrm{C}\end{array}$ & $\begin{array}{c}\text { Duration } \\
\text { of stor- } \\
\text { age }\end{array}$ \\
\hline $12 \ldots 15$ & $9 . .12$ & $\begin{array}{c}\text { is not } \\
\text { limited }\end{array}$ & $10 \ldots 12$ & $\begin{array}{l}\text { is not } \\
\text { limited }\end{array}$ & $10 . .12$ & $\begin{array}{c}\text { is not } \\
\text { limited }\end{array}$ \\
\hline $15 \ldots 16,5$ & $8 . .10$ & $\begin{array}{c}1 \ldots 1,5 \\
\text { years }\end{array}$ & $9 \ldots 10$ & $\begin{array}{l}\text { is not } \\
\text { limited }\end{array}$ & $9 \ldots 10$ & $\begin{array}{c}\text { is not } \\
\text { limited }\end{array}$ \\
\hline $16,5 \ldots 18$ & $5 \ldots 7$ & $\begin{array}{c}4 \ldots 6 \\
\text { months }\end{array}$ & $8 \ldots 10$ & $\begin{array}{l}5 \ldots 10 \\
\text { months }\end{array}$ & $8 \ldots 10$ & $\begin{array}{c}6 . .13 \\
\text { months }\end{array}$ \\
\hline $18 \ldots 20$ & 5 & $\begin{array}{c}2 \ldots 3 \\
\text { months }\end{array}$ & $8 \ldots 10$ & $\begin{array}{c}2 \ldots 7 \\
\text { months }\end{array}$ & $9 \ldots 10$ & $\begin{array}{c}\ldots 9 \\
\text { months }\end{array}$ \\
\hline $20 \ldots 22$ & 5 & $\begin{array}{c}3 \ldots 4 \\
\text { weeks }\end{array}$ & $6 \ldots 8$ & $\begin{array}{l}4 \ldots 16 \\
\text { weeks }\end{array}$ & $6 \ldots 8$ & $\begin{array}{c}5 . .20 \\
\text { weeks }\end{array}$ \\
\hline
\end{tabular}

The ecological positive aspect of the low-temperature storage method is related to the fact that

technological process excludes high-temperature drying with a mixture of flue gases and air and accordingly, the possibility of contamination with carcinogenic substances, for example, benzapyrene, is eliminated. The cooled grain does not contain hydrocarbons, soot, sulfur and nitrogen oxides, heavy metals, nitrites and nitrates [3] and does not require additional cleaning costs.

Technologies of artificial cold application are used in many countries of the world - in the USA, Germany, Japan, Australia, Brazil [3]. So, for example, Germany widely uses technology of low-temperature grain processing - annually it is cooled up to 70 million tons of grain [9].

To serve the vast majority of consumers in the world, the transnational corporation "GRANIFRIGOR" produces mobile refrigeration units based on vapor compression refrigeration units. Mobile refrigeration units periodically cool the silos by blowing a column of grain with chilled air. In the mid-1990s, mobile (on a mobile platform) THU-502-0 refrigeration unit (cooling capacity $37,000 \mathrm{kcal} / \mathrm{h}$ ) was introduced in Trostyanets Grain Receiving Enterprise in Ukraine to cool the grain in a typical 3200-tonne warehouse with air [3].

Known experience in the use of stationary cooling plants in the Russian Federation $[3,6]$ for storage of rice, which has not received further distribution.

It should be noted that among all types of cereal products of particular interest for low-temperature

drying is a variety of fine grains (rapeseed, flax, millet, mustard, amaranth, etc.). Due to their insignificant characteristic linear dimension, they are most susceptible to damage during drying by heating [3]. For this type of grain, there is no standard cooling equipment, since heat transfer processes and hydraulic regimes when blowing a fixed layer of small-seed grain with cooled air in currently not studied.

\section{Purpose and objectives of the study}

The purpose of this study is to assess the prospects for using different types of refrigeration machines for lowtemperature grain storage and the development of such systems for fine grain.

To achieve this goal it is necessary to accomplish the following tasks:

- to evaluate the prospects of using different types of refrigeration machines for low-temperature processing of small seeds;

- carry out experimental studies of heat transfer processes in a low-temperature processing of small seeds;

- to develop perspective schemes of cooling systems for primary low-temperature processing

A preliminary analysis showed [3] that the prospects for use in mobile cooling systems

Grain can have a vapor compression refrigeration machine (VCRM) and a gas refrigerating machine (GRM).

The advantages of GRM include the absence of problems with the working air body, they are easy to operate and do not have anthropogenic impact on the ecosystem of the planet.

The drawbacks of GRM include high weight and size parameters and low energy efficiency [10].

The use of VCRM in grain cooling systems is currently associated with the transition to ozone-friendly refrigerants.

At present, a whole range of substitutes for traditional refrigerant VCRM - R12 is offered, including including natural ones, for example ammonia $[11,16]$.

To determine the prospects for using traditional and new refrigerants, a thermodynamic analysis of the VCRM cycles was carried out.

The calculation of the VCRM cycle was carried out for the following conditions [12]. The boiling point of the refrigerants is taken into account taking into account the optimal level of grain storage temperatures $\left(5^{\circ} \mathrm{C}\right.$ and $\left.10^{\circ} \mathrm{C}\right)$, the driving temperature head between the grain and the cooled air $\left(10^{\circ} \mathrm{C}\right)$ and the temperature drop in a typical air cooler $\left(10{ }^{\circ} \mathrm{C}\right)$, i.e., - minus $15^{\circ} \mathrm{C}$ and minus $10^{\circ} \mathrm{C}$. The condensation temperature of the refrigerants $\left(40^{\circ} \mathrm{C}\right)$ is taken into account when VCRM is operated at an ambient temperature of $32^{\circ} \mathrm{C}$ and the temperature difference in a typical air condenser $\left(8 \ldots 10^{\circ} \mathrm{C}\right)$. The temperature differ- 
ence in the regenerative heat exchanger (RHE) is assumed to be $20^{\circ} \mathrm{C}$. In VCRM with $\mathrm{R} 717$, as a refrigerant, RHE is traditionally absent. The results of calculating the energy characteristics of such VCRM cycles are given in Table. 2.

Analysis of the results presented in Table. 2, shows that the greatest prospects in mobile systems of grain cooling has a natural refrigerant - ammonia, which is also excellent ecological characteristics.

Table 2 - The calculated values of the energy characteristics of VCRM cycles at different boiling points

\begin{tabular}{|l|c|l|l|l|}
\hline $\begin{array}{c}\text { Number } \\
\text { refrig- } \\
\text { erant }\end{array}$ & $\mathbf{q}_{\mathbf{0}}$ & $\mathbf{I}$ & COP & $\boldsymbol{\eta}$ \\
\hline R22 & $\begin{array}{c}168 \\
(170)\end{array}$ & $\begin{array}{c}44 \\
(38)\end{array}$ & $\begin{array}{c}3,82 \\
(4,47)\end{array}$ & $\begin{array}{c}81,4 \\
(85,0)\end{array}$ \\
\hline R134 & 152 & 41 & 3,71 & 79,1 \\
& $(154)$ & $(39)$ & $(3,95)$ & $(75,1)$ \\
\hline R404A & 115 & 39 & 2,94 & 62,9 \\
& $(118)$ & $(34)$ & $(3,47)$ & $(66,0)$ \\
\hline R407C & 160 & 49 & 3,27 & 69,6 \\
& $(162)$ & $(43)$ & $(3,77)$ & $(71,6)$ \\
\hline R410A & 167 & 55 & 3,04 & 64,7 \\
& $(172)$ & $(55)$ & $(3,13)$ & $(59,5)$ \\
\hline R507A & 112 & 40 & 2,80 & 59,7 \\
& $(116)$ & $(39)$ & $(2,94)$ & $(56,5)$ \\
\hline R717 & 1047 & 278 & 3,77 & 80,3 \\
& $(1053)$ & $(242)$ & $(4,35)$ & $(82,7)$ \\
\hline
\end{tabular}

Note: 1 - the characteristics for the boiling point of the refrigerant is minus $10^{\circ} \mathrm{C} ; 2$ - Summary values: q0 - specific cooling capacity, $\mathrm{kJ} / \mathrm{kg} ; \mathrm{l}$ - is the specific work of compression, $\mathrm{kJ} / \mathrm{kg} ; \eta$ - is the degree of thermodynamic perfection, \%

Despite the widespread use of VCRM at present [9], it is possible to speak about certain

perspectives of absorbing refrigeration machines (ARM) and steam-jet refrigeration machines (SJRM) type in stationary grain cooling systems [10]. ARM and SJRM use, as a rule, heat of low temperature potential, for example, heat of exhaust gases of internal combustion engines, waste heat of gas turbine units and boilers. Electric energy in ARM and SJRM is used only for driving pumps and in automation systems, and in ARM in the total energy supply, the share of electricity is from $0.5 \%$ (bromide-lithium units [13]) to $2.3 \%$ (water-ammonia [13]), in the SJRM 0.6\% [14]. Brine-bridging lithium ARM provides cooling of objects to $6 \ldots 12{ }^{\circ} \mathrm{C}$ with a thermal coefficient of $0.64 \ldots 0.69$ [13].

The thermal coefficient of serial SJRM in the range of cooling temperatures $4 \ldots 8^{\circ} \mathrm{C}$ is $0.06 \ldots 0.13$ with a cooling capacity of $350 \ldots 1150 \mathrm{~kW}$ [13].

Let's compare VCRM with compressor P220 and ammonia as a refrigerant.

Calculations show that the refrigerating coefficient of such VCRM at a boiling point of $5^{\circ} \mathrm{C}$ and the condensation temperature of $30^{\circ} \mathrm{C}$ is 7.5 , and the cooling capacity is $650 \mathrm{~kW}$ [16]. In this case, the cost of electricity to produce 1 kilowatt of artificial cold is $0,13 \mathrm{~kW}$; in bromistolite ARM - $0.008 \mathrm{~kW}$, water-ammonia ARM - $0.04 \mathrm{~kW}$; SJRM $-0.1 \mathrm{~kW}$.
These results lead to the conclusion that in the presence of waste energy resources, operating costs for all types of heat-utilizing refrigerating machines (ARM and SJRM) are lower than for VCRM.

\section{Experimental studies of low-temperature treat- ment of small-seed cultures}

To solve these problems, studies were carried out on a specially manufactured laboratory unit. The object of research was selected grain of rape [1].

A schematic diagram of the experimental setup is shown in Fig. 1.

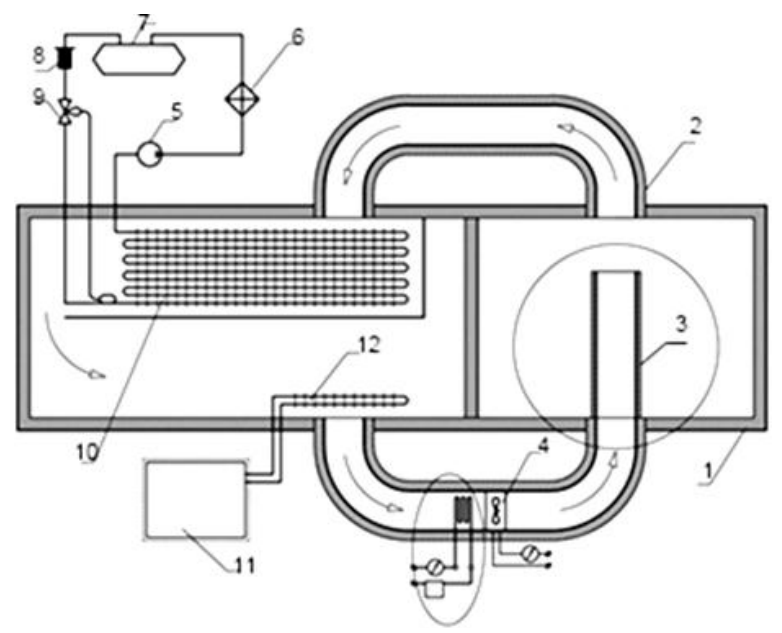

Fig. 1. The scheme of the stand for the study of modes lowtemperature grain treatment of small-seed cultures: 1 - the refrigerating chamber; 2 - air ducts; 3 - experimental cell; 4 - the fan; 5 - the compressor; 6 - air condenser; 7 - receiver; 8 - filter drier; 9 - thermostatic expansion valve; 10 evaporator; 11 - additional refrigerating unit; 12 - evaporator.

The installation consists of a rectangular insulated $(\delta=$ $30 \mathrm{~mm})$ body $1(1900 \times 500 \mathrm{~mm})$ with a height of $570 \mathrm{~mm}$, divided into two compartments by a partition. The air ducts 2 connecting the two compartments are made of plastic pipes in the form of a pipe-in-pipe construction, between tubes space is filled with polyurethane foam. In one compartment heat treatment of air takes place before feeding to the grain cooling. In the other compartment there is experimental cell 3, which is a cylindrical hopper with a height of $370 \mathrm{~mm}$, the inner diameter of which is $104 \mathrm{~mm}$, insulated from the outside. A small metal mesh in the form of a sieve is fixed in the lower part, and the upper one is open. To visualize the level of the processed small-seed grain in the bunker, transparent window in height with a measuring scale. In the lower duct there is an injection fan 4 rotation speed, which is regulated by LATR. Also an electric heater is installed, which allows to heat the air of the grain that is going to heat treatment. An air-to-air unit is used for air cooling, which consists of a sealed compressor 5 with a suction valve, a ribbed tube air condenser 6 with a diffuser, a receiver 7 with a shut-off liquid valve, a filter dryer 8 , a fan with an electric motor, and pipelines connecting the compressor, condenser, receiver and filter-drier, mounted on a steel stamped plate. The complete set of the unit includes a shield of electrical equipment consisting of an au- 
tomatic fuse and a magnetic starter. For automatic control of the compressor is used thermostatic valve 9, pressure switch, for visual monitoring of compressor operation pressure gauge and a vacuum gauge. A finned coil battery 10 is used as the cooling device.

In order to more accurately maintain the air temperature that is fed to the grain processing, an additional refrigerating unit 11 (with a cooling capacity of $150 \mathrm{~W}$ ) was installed, which includes a hermetic piston compressor, a ribbed coil air condenser, and a filter drier. The evaporator is a finned double-row coil battery 12 .

The method of experimental research was as follows. A chiller was switched on and the unit went out to a predetermined temperature and humidity regime. Pre-prepared rape seed, moistened and heated in a thermostat, was placed in an experimental cell. The height of the backfill was determined by a measuring scale on a transparent window of $100 \mathrm{~mm}, 200 \mathrm{~mm}$ and $275 \mathrm{~mm}$, respectively. At first, the mass of the cell itself was weighed on the laboratory electronic scales, and then together with the grain. The grain temperature was determined by means of resistance thermometers with a digital output to the electronic unit.

The cell was installed in the chamber, and the design of the cell-duct connection provided hermetic quickdetachable connection, which does not allow lateral leakage of air during the purging of the grain.

The velocity and air flow were measured at the outlet of the experimental cell. To determine the speed and air flow, a micromanometer and a Pitot differential tube were used. Time tracked by stopwatch. Every $60 \mathrm{~s}$ the cell was removed and weighed on electronic

laboratory scales, and also measured the temperature of the grain in the upper part (at a distance of $10 \mathrm{~mm}$ from the edge at the rash) and in the middle part of the mound. After this, the experimental cell was placed in a cooling chamber and the experiment continued. During the experiment, the temperature of the air entering the cooling of the grain and leaving after heat treatment was also measured. The experiments were carried out with the same grade of grain, which had the same initial temperature and humidity. The speed, flow rate and temperature of the cooling air were also the same in all the experiments.

Each experiment ended when the same grain temperature was reached at the top of the embankment, regardless of the height of the layer. The initial and final moisture content of the grain was determined in the laboratory conditions on the SESH-3M instrument.

Experimental studies of the kinetics of cooling of small-seed cultures from cooling regimes, such as rapeseed and millet seeds, have been carried out.

Curves are obtained for changes in the rate of cooling of the grain in time and moisture content of the grain, depending on the temperature decrease (Fig.2, Fig.3).

\section{Processing and analysis of experimental data}

Analysis of equations describing the process of heat exchange between the filtering gas and the surface particles can be described in the form of the following criterial equation [17]:

$$
N u=a \cdot \operatorname{Re}_{\ni}^{b} \cdot \operatorname{Pr}^{0.33}
$$

where a, b - empirical coefficients, determined experimentally;

$\operatorname{Re}_{\ni}=\frac{4 \Phi \operatorname{Re}}{6(1-\varepsilon)} ; \operatorname{Re}_{\ni}=\frac{v \cdot d \cdot \rho}{\mu} ;$

$v$ - true gas velocity, $\mathrm{m} / \mathrm{s}$;

$\Phi=\frac{\pi d_{u}^{2}}{4 S}$ - coefficient of sphericity of particles by volume

$V=\frac{\pi d_{u}^{3}}{6}$

and midel section $\mathrm{S}$.

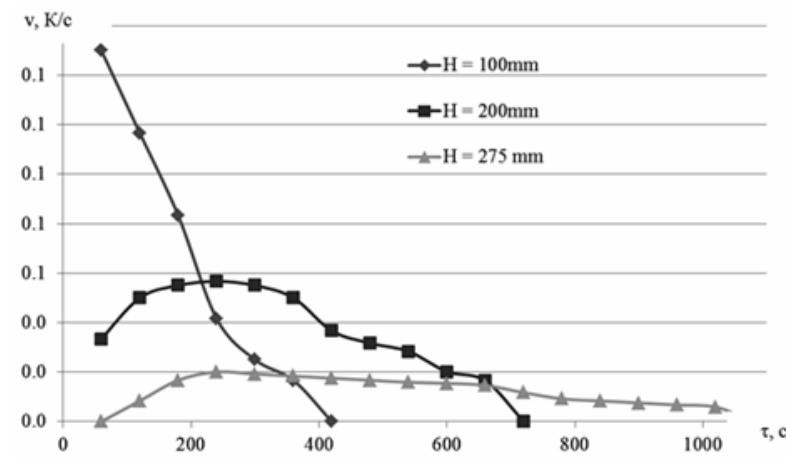

Fig. 2. Graph of changes in the rate of grain cooling over time

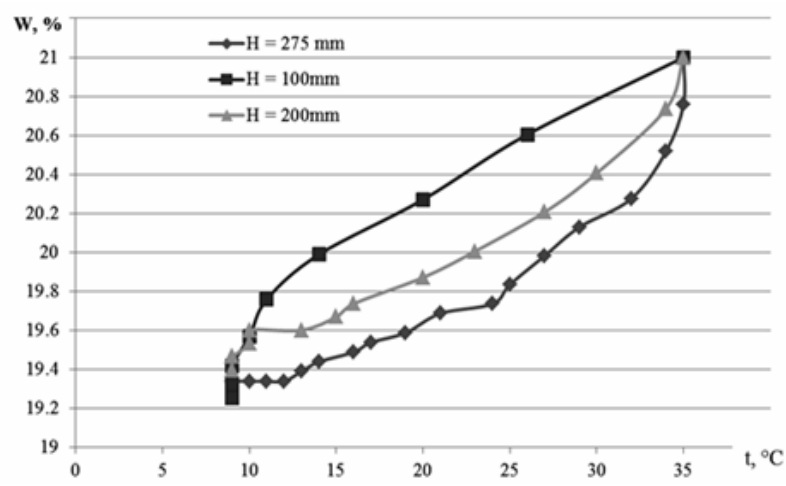

Fig. 3. Graph of the change in moisture content of grain as a function of temperature decrease

To calculate the convective heat transfer of granular material and cold air, we used the equation

$$
N u=2\left(1+0.276 \cdot \operatorname{Re}^{1 / 2} \cdot \operatorname{Pr}^{1 / 3}\right)(1)
$$

The criterion equation (1) was supplemented with a simplex $\mathrm{d} / \mathrm{h}$, which takes into account the loading height (h) and the dimeter layer $(\mathrm{d})$.

The general form of the equation describing the process of cooling the grain of a spherical shape, to which the investigated rape seed belongs, can be represented as:

$$
N u=2+a \cdot \operatorname{Re}_{\ni}^{0.5} \cdot \operatorname{Pr}^{0.33} \cdot\left(\frac{d}{h}\right)^{b}
$$

where $\mathrm{Nu}$ is the Nusselt criterion, $N u=\frac{\alpha \cdot d}{\lambda}$;

$\operatorname{Pr}$ - Prandtl criterion, $\operatorname{Pr}=\frac{\mu \cdot c}{\lambda}$;

$\alpha$ - is the heat transfer coefficient from moving air to grain, $\mathrm{W} /\left(\mathrm{m}^{2} / \mathrm{K}\right)$; 
$\lambda$ - coefficient of thermal conductivity of air, W / (m K);

$\mu$ - is the coefficient of dynamic viscosity, $\mathrm{Pa} \mathrm{c}$;

$\mathrm{c}$ - is the heat capacity of the air, $\mathrm{J} / \mathrm{kg} \mathrm{K}$;

$\mathrm{d}$ - is the diameter of the pipe, $\mathrm{m}$.

$\mathrm{a}, \mathrm{b}$ - empirical coefficients to be determined

experimentally.

To determine the unknown coefficients in Eq. (2), a well-known technique was used [19].

An equation for determining the convective heat transfer coefficient for a refrigerating processing of rape seeds:

$$
N u=2+0.2 \cdot \operatorname{Re}_{\ni}{ }^{0.5} \cdot \operatorname{Pr}^{0.33} \cdot\left(\frac{d}{h}\right)^{1.423}
$$

Range of simplex change: $1,1 \leq\left(\frac{d}{h}\right) \leq 0,37$

In Fig. 3 compares the results of experimental studies and obtained by the equation (3).

The relative error in determining the heat transfer coefficient does not exceed $10 \%$ (Figure 4), which allows us to use equation (2) for the design of primary refrigeration systems small-seed grain.

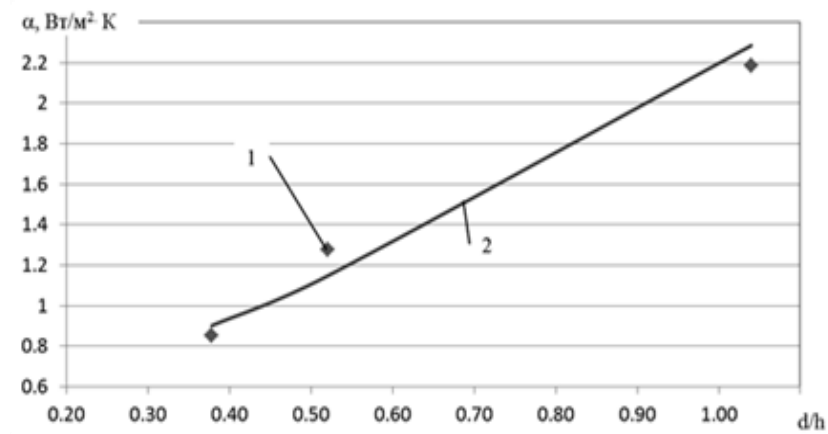

Fig. 4. Graph of the change in the heat transfer coefficient from air to the grain layer: 1 - experiment, 2 - calculation

\section{Advanced design solutions for primary low- temperature processing systems small-seed cul- tures}

Based on the experimental data on the heat transfer between cooled air and grain, model studies of the temperature and hydrodynamic fields of the embankment smallseed grain.

At the heart of mathematical models lie the known positions on heat exchange of air flow and

fixed grain embankment and distribution of velocity fields under these conditions [18-21].

The result of the simulation is two technical proposals.

\section{1 Primary cooling system of container type}

The cooled container (Figure 5) [22] is a box 1 with airtight external fences without a top cover and with a perforated bottom. On the side there is a hatch 2 for unloading the grain. To the bottom of the container is fixed the air distributor 3 in the form of a cone, to which, in turn, the air duct 6 is connected to the hinges (springs) 4 by means of a movable connection 5 . In the side walls, guides 7 are provided for tight fitting to a nearby standing container. In this case, the construction of the connection of the air ducts to each other allows this automatically when the next adjacent container is installed due to the coupling. It additionally it contains the platform 8 on which it is installed.

The process is as follows. Containers are filled with grain mass and installed in a storage facility for grain storage. And the first container joins the general distribution duct. Each subsequent container fits snugly into the front, and the air ducts 6 are automatically connected in a single line. This is provided by the guides 7 , hinges (springs) 4 and a special design of the coupling. The last container installed in the row has a plug at the end of the duct. The number of rows is determined by the size of the warehouse.

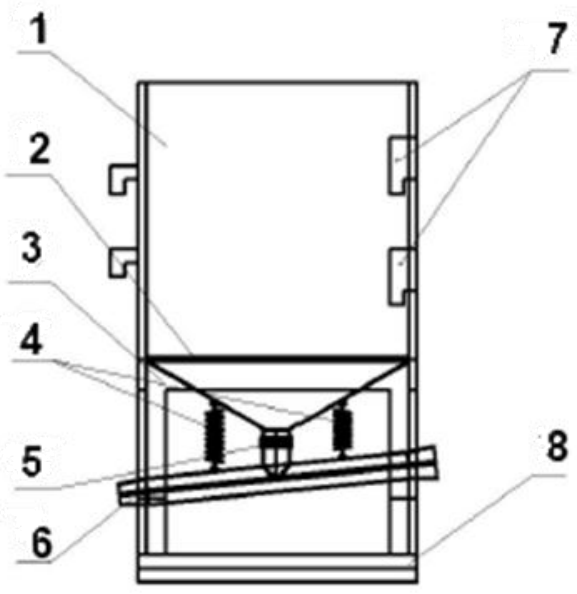

Fig. 5. Scheme of the container for the primary lowtemperature cooling of small-seed grains:

1 - housing; 2 - hatch for grain unloading;

3 - the air distributor; 4 - suspended springs;

5 - movable connection; 6 - the air duct;

7 - guides; 8 - installation platform

6.2 The cooling system of a warehouse for the outdoor storage of a moist grain of small seeds

The technical proposal is shown in Fig. 6, a-c.

The design is supposed to be installed in the places of direct harvesting of grain. Grain is loaded into separate partitions, in the lower part of which there are channels for supplying chilled air.

To prevent the grain from being poured in the lower part of the partitions, perforated grilles are installed.

The exhaust air is vented by ducts from the top of the storage.

\section{Discussion of the results of the development of cooling systems for the primary low-temperature processing and storing grain of small-seed crops}

The merits of the study include:

- the executed analysis and a substantiation of prospects of a way of low-temperature processing and grain storage of small-seed crops, as well as an analysis of the types of refrigeration machines that can be effectively used in such systems;

- novelty of the results of an experimental study of heat transfer processes between cold air and fixed filling of small seeds (on the example of rapeseed); 
- new designs of systems for primary low-temperature treatment of small-seed crops, which can be used in farming in Ukraine.

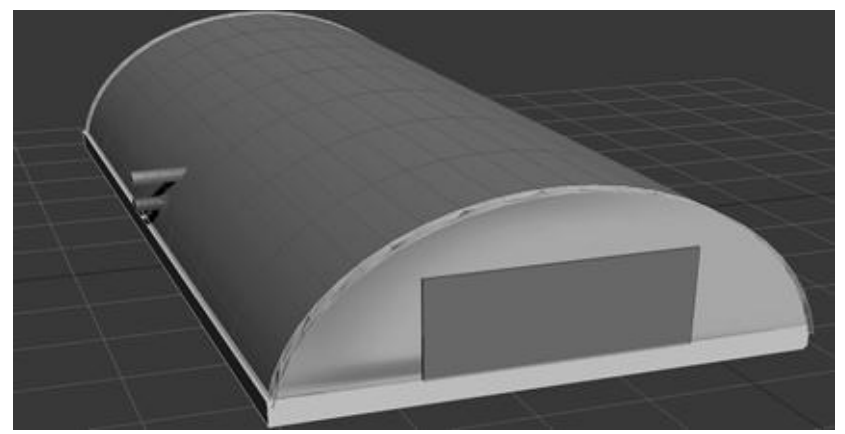

a)

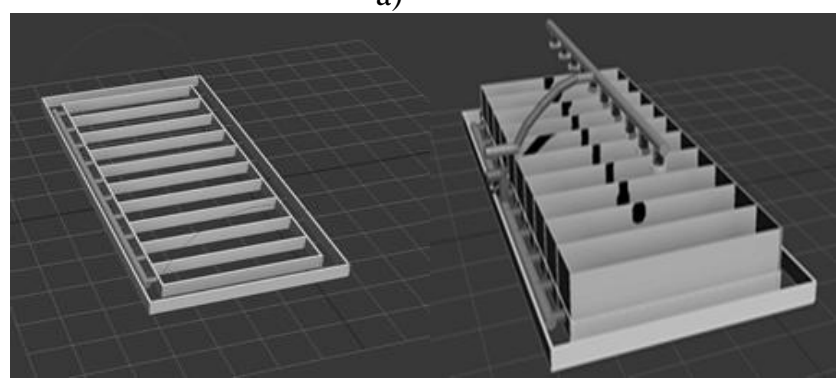

b)

c)

Fig. 6. Storage system for floor storage wet grain of smallseed crops: a - general view of the warehouse; b-system distribution of air flows.

The shortcomings of the work include:

- study of small-seed grain only on the example of rape, which does not allow to generalize the results

on other crops;

- the absence in the article of the results of mathematical modeling of thermal and gas dynamic regimes during refrigeration treatment of small seeds by air flow.

The conducted researches are useful for developers of systems of primary low-temperature processing of smallseed cultures.

The developed systems of primary low-temperature processing of small-seed crops can be widely used in farmers 'and peasants' economies of Ukraine, first of all, due to the simplicity of manufacturing and use of known materials and equipment.

The presented work is a new one and it is planned to continue it in the framework of state budget and postgraduate studies.

\section{Conclusions}

1. An assessment of the prospects of using refrigerating machines, realizing various methods of obtaining artificial cold, showed that:

- lithium bromide and water ammonia AXM (bromide-lithium and water ammonium) and PECM can be recommended as stationary refrigeration units at grain elevators and grain storage sites in Ukraine and CIS countries, and due to the high cost of stationary systems based on
PKHM, the use of cheap environmentally friendly heatpromising in the near future;

- the greatest prospects in mobile grain cooling systems based on PKHM has a natural refrigerant - ammonia, which also has excellent environmental characteristics;

- in the near future in the grain cooling systems of stationary type, PEHM with refrigerant R134a can be used they provide the possibility of using low-potential heat at the temperature level plus $70 \ldots 80^{\circ} \mathrm{C}$, their structures are compact, and the pressure in

the system is maintained above atmospheric, which eliminates air sucking in the evaporator.

2. Experimental studies of convective heat transfer during purge fixed layer of small-seed grain showed that:

- cooling of the grain to $8 \ldots 10^{\circ} \mathrm{C}$ is accompanied by its partial dehumidification: for rapeseed $-1,13 \%$, for millet - $0.98 \%$, with the maximum intensity of moisture entrainment observed at the beginning of heat treatment, thus, for example, when the temperature is reduced by $50 \%$ of the initial grain temperature, the entrainment of moisture is for rapeseed - $90 \%$, millet - $80 \%$;

- the obtained effect of dehydration of the grain upon its cooling allows to exclude from the technological chain process of high-temperature drying, and this will not only reduce energy costs when storing small-seed grains, but also increase its quality.

3. Based on the analysis and the results of experimental studies of convective heat transfer processes, two schemes of primary cooling systems for grain - container (mobile) and stationary type, are proposed, each of which can be used in farmers 'and peasants' economies of Ukraine depending on the volume of processed prod ucts.

\section{References}

1. The Law of Ukraine "On the Fundamentals of National Security of Ukraine" of 19.06.2003. No. 964-IV. Access mode: http://www.nbuv.gov.ua/law/03.

2. Food and Agriculture Organization of the United Nations (FAO) [Electronic source] Access mode: http://www.fao.org/home/en

3. Petushenko, S. (2013). The current state of technology and technology for low-temperature grain processing and storage of small-scale grains. Refrigeration Engineering and Technology, No. 2, 71-74.

4. Malin, N.I. (2004). Energy-saving drying of grain. Moscow: Kolos, 240 p.

5. Petrunya, B.N. (2006). Method of storage of grain using artificially cooled air / B.N. Petrunya, A.I. Ptashchuk // Mixed feed, No. 4, 71-74.

6. Stankevich, G.N., Petrunya, B.N., Bichinyuk, I.I., Lischenko, Y.V. (2001). Conservation of grain mass with using artificially cooled air // Research works of Odessa National Academy of Food Technologies, Iss. 21, 39-41.

7. Novitska, N., Stepanenko, Yu.S. Yakost nasinya polovihh kollezhno vid temperaturnomu regimu zberivanny [Electronic source] E-conference of the Ternopil's'kyi stateof-the-art press conference Naan of Ukraine. Section 1. Agricultural science. Access mode: http://econf.at.ua /publ/konferencija_2014_10_16_17/sekcija_1_silskogospo darski_nauki/jakist_nasinnja_polovikh_kultur_zalezhno_ vid_temperaturnogo_rezhimu_zberigannja/4-1-0-16. 
8. Novitskaya, N. V. (2009). The quality of seeds is the key to success [Electronic source]: mater. Int. scientific internet-conference. Modern Directions of Theoretical and Applied Research, 2009. Access mode: http: //www.sworld. com.ua

9. Installations for grain cooling GRANIFRIGOR тм. Access mode: http://www.frigortec.com/ustanovki-dlyaohlazhdeniyazerna-granifrigor

10. Morozyuk, L.I. (2014) Heat-using refrigerating machines - ways of development and improvement. Refrigeration engineeri and technology, 50(5), 23-29. doi: 10.15673/0453-8307.5/2014.28695

11. Zhelezny, V.P., Zhidkov, V.V. (1996) Ecological and energy aspects of the introduction of alternative refrigerants in refrigeration technology. Donetsk: Donbass, $144 \mathrm{p}$.

12. Titlov, O.S., Petushenko, S.M., Kudashev, S.M. (2011) Development of a cooling complex on the basis of environmentally safe working bodies. Collection of scientific works of Vinnitsa National Agrarian University. Series: Technical sciences, 8, S. 26-31.

13. Shilkin, N.V. Absorption refrigerating machines [Electronic source] Access mode: http://www.abok.ru/ for_spec/articles.php?nid=3873

14. Silman, M.A., Shumelishsky, M.G. (1984) Steamwater ejector refrigerators. Light and food industry, $271 \mathrm{p}$.

15. Chumak, I.G., Nikulshina, D.G. (1988) Refrigeration plants. Designing. Kyiv, $280 \mathrm{p}$.

16. Zhelezny, V.P., Lysenko, O.V., Ovcharenko, V.S. (2000) Ecological-thermoeconomic analysis of the prospects for the use of ammonia in refrigeration equipment. Refrigeration technology, 3, 12-16.
17. Petushenko, S.N. (2013) The results of experimental studies of heat transfer processes in the primary refrigeration treatment of small-seed grain grains. Refrigeration engineering and technology, 3, 64-68.

18. Gorbis, Z.R. (1970) Heat transfer and hydromechanics of dispersed through flows; 2 nd ed., Revised. and additional. Moskow: Energy, 424 p.

19. Kalenderyan, V.A., Boskova I.L., Kalenderyan V.A. (2011) Heat and Mass Transfer in Apparatus with a Dense Dispersed Layer. Kyiv: Word, 184 p.

20. Boshkova, I.L., Georgieish E.V. (2014) Analytical models for calculating the temperature in a material under the influence of internal heat sources: zb. sciences. pr. Actual problems of energy and ecology, 1(45), 33-38.

21. Radchuk, S. (2014) Dozdidzhennia aerodinamichnyh vlastosti nasinnya ripaku [Elektronnyi resurs]. E-conference Ternopil State Agricultural Experimental Station ICSHP NAAS of Ukraine.Section 4. Technical sciences. - Access mode: http://econf.at.ua/publ/konferencija _2014_10_16_ 17/sekcja_4_tekhnichni_nauki/doslidzhennja_aerodinamich nikh_vlastivostej_nasinnja_ripaku / 7-1-0-53

22. Titlov, O.S., Petushenko, S.M., Kudashev, S.M. (2011) Development of a cooling complex on the basis of ecologically safe robotic bodies. Zbirnik naukovyh prac Vinnitskogo national agrarian university. Seriia: Technical sciences, 8, 26-31.

Received 10 July 2017 Approved 08 September 2017 Available in Internet 30 October 2017 